\title{
Assessment of Occupational Health and Safety Measures' Knowledge and Experienced Types of Hazards among Nursing Staff in Rania Hospital
}

Shakhawan Azad Ahmed; Department of Community Health Nursing, College of Nursing, University of Raparin, Rania, Sulaymaniyah, Iraq.

(Correspondence: shaxawanazad641@gmail.com )

Omar Hussein Shareef; Department of Community Health Nursing, College of Nursing, University of Sulaymaniyah, Sulaymaniyah, Iraq.

\section{ABSTRACT}

Background and Objectives: In recent years, significant developments have occurred in occupational health and safety programs designed to prevent and control work-related illness and injury. The aims of the study were to assess knowledge of nurses on occupational health and safety measures in hospital and their experienced type of occupational hazards'.

Methods: A quantitative descriptive study of non-probability sample was conducted on 50 nurses in Rania general hospital. Data was collected from 10th August 2017 to 25th December 2017. A questionnaire was developed for the purpose of data collection which included socio-demographic attributes of the study sample and questions on occupational hazards and occupational health and safety measures. Frequency, percentage and chisquare tests were used for data analysis.

Results: Proper disposal of waste (90\%), Acquainting rights and obligations / career and your job Descriptions (88\%), Using protective clothing (86\%), Having vaccination against infectious diseases within the health facility (76\%), Providing a clinic for employees at work place (74\%), Prompt reporting of accidents/injuries (72\%) were the most items which nurses implied to them according their knowledge. Nurses mentioned that they experienced following occupational hazards in the hospital: physical $48 \%$, psychological $28 \%$, mechanical/electrical $12 \%$, chemical $22 \%$ and biological $10 \%$. There was a significant and highly significant association between years of experience and level of education of nurses with their overall knowledge on occupational health and safety measures, respectively but not with their age.

Conclusions: Nurses did not have complete knowledge regarding occupational health and safety measures and they experienced different types of hazards during their working years.

Keywords: Occupational Health, Occupational Hazards, Work-related Injuries, Workrelated IIIness, Work Safety, Health and Safety.

Received: $15 / 10 / 2018$

Accepted: 18/4/2019

Published: 30/11/2019

\section{INTRODUCTION}

Numerous changes in the nature of work and workplace risks have occurred. Those changes have many impacts on the work environment, demographics of the work force composition, and health care delivery mechanisms. The analysis of these trends suggests that work-health interaction continues to grow in advance including the quality of performance, reducing hazards in workplace and health delivery strategies $[1,2]$. Workers represent half of the global population and contribute greatly to the economic and social value of 
contemporary society. A substantial part of the general morbidity of the working population is related to work [3-4]. Additionally, too many workers are still exposed to unacceptable levels of occupational risks. They remain victims of occupational diseases and work accidents, lose their working capacity and income potential with limited access to occupational health services [5, 6].

Occupational injuries and illness arise from unsafe conditions or activities in the work environment and are usually preventable. Occupational injuries include but are not limited to exposure to chemicals, injuries from sharp objects or machinery, injuries from unsafe working environments such as slippery or uneven floors, poor ventilation, and improper functioning of electricity. The occupational health care provider has a crucial role in addressing work place risks. Indeed the roles of occupational hazards in the work place are to prevent injury and illness, as well as the treatment of injured or ill workers $[7,8]$.

This is especially true for health care providers and, in particular, nurses. Nurses face occupational risks every single day as they work to provide critical health care to their patients. Those risks include, but are not limited to, exposure to infectious diseases, exposure to chemicals, heavy lifting and physical stress, and needle sticks.

Occupational health nurses have performed critical roles in the planning and delivery of worksite health and safety services. These are comprehensive and costeffective services which must continue to grow. The requirements in health care costs and the concern about health care quality have increased significantly. For that reason, safety measures have been established in different settings around the world, including primary care and management of non-work-related health problems in the health services programs [9-10].
We must be aware of our ultimate goal of ensuring that all workers in the world benefit from full physical and mental health. It is still far from being achieved despite the availability of effective interventions for occupational health. Occupational health hazards consist of the biological, physical, mechanical, ergonomic, chemical, psychosocial hazards [1].

The aims of this study were to assess 1 ) occupational and safety measures orientation, 2) knowledge on occupational health and safety in hospital and its association with their age, level of education and year of experience, 3 ) type of occupational hazards' experienced among nurses in Rania general hospital.

\section{METHODS}

A quantitative descriptive study of nonprobability purposive sample was conducted on 50 Nurses from 120 nurses who work in Rania General Hospital who were available during data collection. Data was collected in the period from August 2017 to December 2017. The sample of hospital nurses were selected from different hospital departments including emergency, pharmacy, radiology, surgical and operational room and coronary care unit. A questionnaire was developed for the purpose of data collection in the study. The first part included socio-demographic attributes of the participants. Occupational Health and Safety Measures, Occupational health Hazards and supportive activities were the main domains in the second part of the questionnaire. Six experts in the field reviewed the question are and checklist who suggested some modification in order to improve internal validity of the tool while the reliable of the questionnaire result of correlation was $(r=0.78)$ for the entire questionnaire by test and retest. The study was approved by the Scientific Committee of College of Nursing at 
University of Raparin, as well as University of Sulaimanyah. The formal permission was given by administration of the hospital. Data was collected through face to face interview technique and analysis by SPSS version 21. Variables were analyzed utilizing descriptive and inferential statistics. Descriptive statistical analyses included frequency, percentage, correlation coefficient and chi-square.

\section{RESULTS}

The highest percentage (48\%) of the nurses were aged between 22-29 years. The majority were male (64\%). Regarding of the years of experience, half of them (44\%) had 1-5 years. The majority of the nurses (84\%) graduated from medical institutes while the lowest percentage of them (4\%) are graduates primary nursing school and college. The majority of the sample (74\%) were married while the lowest percentage of them (24\%) were single (Table 1 ).

Table1: Distribution of the nurse's sociodemographic of the study sample

\begin{tabular}{lll}
\hline Items & F & $(\%)$ \\
\hline Age group & & \\
$22-29$ & 24 & $(48)$ \\
$30-37$ & 21 & $(42)$ \\
$38-46$ & 5 & $(10)$ \\
Gender & & \\
Male & 32 & $(64)$ \\
Female & 18 & $(36)$ \\
Years of experiences & & \\
$1-5$ & 22 & $(44)$ \\
6-10 & 17 & $(34)$ \\
$11-16$ & 11 & $(22)$ \\
Level of Education & & \\
Primary nursing school & 2 & $(4)$ \\
Secondary nursing school & 4 & $(8)$ \\
Medical institute & 42 & $(84)$ \\
College of nursing & 2 & $(4)$ \\
Marital status & & \\
Single & 12 & $(24)$ \\
Married & 37 & $(74)$ \\
Divorced & 1 & $(2)$ \\
Total & 50 & $(100)$ \\
\hline
\end{tabular}

The majority of the study sample (82\%) thought that effective occupational health and safety policies have impact on job performance in the hospital. Sixty four per cent of nurses got training sessions regarding occupational health and safety measures. More than half the nurse (58\%) mentioned that they had periodic educational program regarding that and 52\% attend symposium about it (Table 2 ).

The majority of the study sample mentioned that following are components of occupational health and safety measures: Proper disposal of waste (90\%), Acquainting rights and obligations / career and your job Descriptions (88\%), Using protective clothing (86\%), Having vaccination against infectious diseases within the health facility (76\%), Providing a clinic for employees at work place (74\%), Prompt reporting of accidents/injuries (72\%). Only $26 \%$ of the study sample mentioned that they have a medical file within the health facility (Table 3).

Nurses mentioned that they experienced following occupational hazards in the hospital: physical $48 \%$, psychological $28 \%$, mechanical/electrical $12 \%$, chemical $22 \%$ and biological 10\% (Table 4).

Table 5 shows that there was significant and highly significant association between years of experience and level of education of nurses with their overall knowledge on occupational health and safety measures, respectively but not with their age.

Table 5, displays the relationship between level of nurses' education and their knowledge. The distribution of the level of education among participants showed that $84 \%$ graduated from medical institute. This finding is significant for the Kurdistan Region. For several years colleges of nursing and nursing institutions have worked to improve the level of knowledge and 
education of their graduates. This finding indicates that education is critical to nursing practice in the hospitals. The findings suggest that future study of an educational intervention aimed at non graduates who are working as nurses is critical. At the same time, there appears to be a significant relationship between years of experience and knowledge as identified in Table 5.

Table 2: occupational and safety measures orientation among study sample

\begin{tabular}{|c|c|c|c|c|c|c|c|}
\hline \multirow[t]{2}{*}{ No } & \multirow[t]{2}{*}{ Items } & \multicolumn{2}{|c|}{ Yes } & \multicolumn{2}{|c|}{ Not sure } & \multicolumn{2}{|l|}{ No } \\
\hline & & $\mathbf{F}$ & (\%) & $\mathbf{F}$ & $\%$ & $\mathbf{F}$ & (\%) \\
\hline 1 & $\begin{array}{l}\text { Do you think effective occupational health } \\
\text { and safety policies have any impact on job } \\
\text { performance in the hospital? }\end{array}$ & 41 & (82) & 3 & (6) & 6 & (12) \\
\hline 2 & $\begin{array}{l}\text { Did you get training sessions about occu- } \\
\text { pational health and safety measures? }\end{array}$ & 32 & (64) & 1 & (2) & 17 & (34) \\
\hline 2 & $\begin{array}{l}\text { Did you have periodic educational pro- } \\
\text { gram in your department regarding occu- } \\
\text { pational health and safety measures? }\end{array}$ & 29 & (58) & 2 & (4) & 19 & (38) \\
\hline 3 & $\begin{array}{l}\text { Did you attend any symposia regarding } \\
\text { occupational health and safety measures? }\end{array}$ & 26 & (52) & 2 & (4) & 22 & (44) \\
\hline
\end{tabular}

Table 3: Knowledge regarding occupational health and safety measures in hospital

\begin{tabular}{|c|c|c|c|c|c|c|c|}
\hline \multirow[t]{2}{*}{ No } & \multirow[t]{2}{*}{ Items } & \multicolumn{2}{|l|}{ Yes } & \multicolumn{2}{|c|}{ Not sure } & \multicolumn{2}{|l|}{ No } \\
\hline & & $\mathbf{F}$ & $(\%)$ & $\mathbf{F}$ & $(\%)$ & $\mathbf{F}$ & $(\%)$ \\
\hline 1 & Proper disposal of waste. & 45 & $(90)$ & 1 & $(2)$ & 4 & (8) \\
\hline 2 & $\begin{array}{l}\text { Regular monitoring on safety and health standards to en- } \\
\text { sure if they are complied with. }\end{array}$ & 30 & $(60)$ & 7 & (14) & 13 & $(26)$ \\
\hline 3 & Using protective clothing & 43 & (86) & 3 & (6) & 4 & (6) \\
\hline 4 & Prompt reporting of accidents/injuries & 36 & $(72)$ & 7 & (14) & 7 & (14) \\
\hline 5 & Re-training on safety and health practices & 21 & $(42)$ & 7 & $(14)$ & 22 & $(44)$ \\
\hline 6 & Having a safety committee in the hospital & 29 & $(58)$ & 6 & $(12)$ & 15 & $(30)$ \\
\hline 7 & $\begin{array}{l}\text { Having written copy of occupational health and safety } \\
\text { policy of the hospital in department }\end{array}$ & 30 & $(60)$ & 7 & $(14)$ & 13 & $(26)$ \\
\hline 8 & $\begin{array}{l}\text { Providing protective devices especially the safety of the } \\
\text { work environment }\end{array}$ & 26 & $(52)$ & 9 & (18) & 15 & $(30)$ \\
\hline 9 & $\begin{array}{l}\text { Having vaccination against infectious diseases within the } \\
\text { health facility }\end{array}$ & 38 & $(76)$ & 4 & (8) & 8 & $(16)$ \\
\hline 10 & $\begin{array}{l}\text { Acquainting rights and obligations / career and your job } \\
\text { Descriptions }\end{array}$ & 44 & (88) & 2 & (4) & 4 & (8) \\
\hline 11 & Having a medical file within the health facility & 13 & $(26)$ & 3 & (6) & 34 & (68) \\
\hline 12 & Providing a clinic for employees at work place & 37 & (74) & 5 & $(10)$ & 8 & $(16)$ \\
\hline 13 & Reporting the accident to the appropriate authorities & 19 & (38) & 13 & $(26)$ & 18 & $(36)$ \\
\hline
\end{tabular}


Table 4: Type of occupational hazards' experienced by study sample

\begin{tabular}{|c|c|c|c|c|c|c|c|}
\hline \multirow[t]{2}{*}{ No } & \multirow[t]{2}{*}{ Items } & \multicolumn{2}{|c|}{ Yes } & \multicolumn{2}{|c|}{ Not sure } & \multicolumn{2}{|l|}{ No } \\
\hline & & $\mathbf{F}$ & (\%) & $\mathbf{F}$ & (\%) & $\mathbf{F}$ & (\%) \\
\hline 1 & $\begin{array}{l}\text { Physical: falling, sliding, back injuries, muscle, needle } \\
\text { stick? }\end{array}$ & 24 & (48) & 4 & (8) & 22 & (44) \\
\hline 2 & $\begin{array}{l}\text { Psychological: work pressure, the violence of the pa- } \\
\text { tient and his family? }\end{array}$ & 14 & (28) & 9 & (18) & 27 & (54) \\
\hline 3 & $\begin{array}{l}\text { Mechanical, electrical: electrical injuries when using } \\
\text { electrical appliances? }\end{array}$ & 6 & (12) & 8 & (16) & 36 & (72) \\
\hline 4 & $\begin{array}{l}\text { Chemical: exposure to chemicals such as acids and tox- } \\
\text { ins and those that lead to a fire or explosion, and clean- } \\
\text { ing materials and dust? }\end{array}$ & 11 & (22) & 3 & (6) & 36 & (72) \\
\hline 5 & Biological: bacteria, viruses and mildew? & 5 & (10) & 0.0 & (0) & 45 & (90) \\
\hline
\end{tabular}

Table 5: Association between age, level of education, years of experience of the study sample and their overall knowledge on occupational health and safety measures in hospital

\begin{tabular}{|c|c|c|c|c|c|c|c|}
\hline & \multicolumn{2}{|l|}{ No } & \multicolumn{2}{|c|}{ Not sure } & \multicolumn{2}{|c|}{ Yes } & \multirow[t]{2}{*}{$p$-value } \\
\hline & $\mathbf{F}$ & (\%) & $\mathrm{F}$ & (\%) & $F$ & (\%) & \\
\hline \multicolumn{8}{|l|}{ Age group years } \\
\hline $22-29$ & 248 & (36.9) & 65 & (9.7) & 359 & (53.4) & \multirow{3}{*}{$\begin{array}{c}0.948 \\
\text { NS }\end{array}$} \\
\hline $30-37$ & 227 & (38.6) & 72 & (12.1) & 290 & (49.3) & \\
\hline $38-48$ & 50 & (35.7) & 15 & (10.7) & 75 & $(53.6)$ & \\
\hline \multicolumn{8}{|l|}{ Level of education } \\
\hline primary nursing school & 10 & (17.9) & 3 & (5.4) & 43 & (76.9) & \\
\hline $\begin{array}{l}\text { secondary nursing } \\
\text { school }\end{array}$ & 51 & $(45.5)$ & 15 & (13.4) & 46 & (41.1) & $\begin{array}{c}0.005 \\
\text { HS }\end{array}$ \\
\hline medical institute & 444 & (37.8) & 124 & $(10.5)$ & 608 & (51.7) & \\
\hline nursing college & 22 & (29.3) & 7 & $(2.51)$ & 27 & $(58.2)$ & \\
\hline \multicolumn{8}{|l|}{ Years of experiences } \\
\hline \multirow[t]{2}{*}{$1-5$} & 216 & (35.1) & 72 & $(11.7)$ & 328 & $(53.2)$ & \\
\hline & & & & & & & 0.01 \\
\hline $6-10$ & 195 & (41) & 48 & $(10.1)$ & 233 & (48.9) & $\mathbf{S}$ \\
\hline $11-16$ & 114 & (37) & 31 & (10.1) & 163 & (52.9) & \\
\hline
\end{tabular}




\section{DISCUSSION}

Table 5, displays the relationship between level of nurses' education and their knowledge. The distribution of the level of education among participants showed that $84 \%$ graduated from medical institute. This finding is significant for the Kurdistan Region. For several years colleges of nursing and nursing institutions have worked to improve the level of knowledge and education of their graduates. This finding indicates that education is critical to nursing practice in the hospitals. The findings suggest that future study of an educational intervention aimed at non graduates who are working as nurses is critical. At the same time, there appears to be a significant relationship between years of experience and knowledge as identified in Table 5. This is worth noting as "learning on the job" and by being exposed to nurses who have greater knowledge could have an effect on nursing practice. This must be studied further. Regarding educational programs on occupational health and safety, the findings indicate that $82 \%$ of the nurses surveyed think that they should have training on occupational health and safety. This is highly significant to the overall study and should inform future educational interventions. Only $52 \%$ of those surveyed indicated that they had any safety training during orientation. Indeed, the results from these results are extremely significant to future studies and any interventions that are planned for occupational health and safety.

The current study explored that, using all the necessary personal protective equipment was associated with reduced exposure to both biological and non-biological hazards. This finding supports evidence by Hayden et al., who reported that use personal protective equipment reduced acquisition of illnesses in hospital settings [12]. Indeed, use and compliance with utilization of personal protective equipment has for long been recognized as important infection control measure in the healthcare industry $[13,14]$ which should be emphasized to minimize exposure to occupational hazards.

These findings are largely comparable to previous studies conducted in low and middle income countries. Ziraba in Uganda, Nsubuga in Uganda, Orij in Nigeria, De Castro in Philippines, and Adib-Hajbaghery in Iran reported that sharp related injuries and stress were the major health related hazards experienced by healthcare workers in their studies [15-16].

Although many health facilities provided special waste disposal containers for medical wastes and safety tools and equipment as control measures for occupational health hazards, simple measures like hand washing were not fully embraced. The proportion of health workers who reported washing hands after recommended procedures was lower than has been reported by previous studies $[17,18]$.

The study also found that, respondents who experienced work related pressures were more likely to report occupational hazards. Work related pressures have been reported to have negative impacts including the compromise of patient care thus resulting to a diminished quality of life for both healthcare workers and patients [19]. The findings with regard to training of staff are also comparable with those of a study that was carried out on the relationship between employees' perceptions of safety and organizational culture where insufficient safety training was the root cause of major accidents at the work place since employees did not have the knowledge and skills to identify potential hazards $[20,21]$.

In a similar study, organizations which emphasized on safety through training and other managerial practices observed an 
increase in safety compliance among their employees [23]. Other similar study further reported that employees who have received safety training will likely report less work-related injuries than their untrained counterparts [22].

\section{CONCLUSION}

The study showed that the most significant factor in relation to occupational health and safety practice was related to nurses' knowledge. It is important to continue to train nurses in university and institution educational settings on the importance of occupational health and safety. It is also recommended that all hospitals should establish an orientation unit related to occupational health and safety not only for their new nursing employees, but also for all employees. Third, it is important to have and evaluate continuing educational programs on occupational health and safety. Overall, this study is important in informing future interventions and practice for nurses on occupational health and safety.

\section{CONFLICT OF INTEREST}

The authors reported no conflict of inter-

\section{REFERENCES}

ests.

[1] Bolyard EA, Tablan OC, Williams WW, Pearson ML, Shapiro CN, Deitchman SD, Hospital Infection Control Practices Advisory Committee. Guideline for infection control in healthcare personnel, 1998. Infection Control \& Hospital Epidemiology. 1998 Jun;19 (6):407-63.

[2] Burgel BJ, Childre F. The occupational health nurse as the trusted clinician in the 21st century. Workplace health \& safety. 2012 Apr;60 (4):143-50.
[3] Gitlin DF, Schindler BA, Stern TA, Epstein SA, Lamdan RM, McCarty TA, et al: Worley LL. Recommended guidelines for consultationliaison psychiatric training in psychiatry residency programs: A report from the Academy of Psychosomatic Medicine Task Force on psychiatric resident training in consultationliaison psychiatry. Psychosomatics: Journal of Consultation and Liaison Psychiatry. 1996 Jan.

[4] Hayden MK, Blom DW, Lyle EA, Moore CG, Weinstein RA. Risk of hand or glove contamination after contact with patients colonized with vancomycin-resistant enterococcus or the colonized patients' environment. Infection Control \& Hospital Epidemiology. 2008 Feb;29(2):149-54.

[5] Singer AJ, Clark RA. Cutaneous wound healing. New England journal of medicine. 1999 Sep 2;341(10):738-46.

[6] Marais BJ, Raviglione MC, Donald PR, Harries $A D$, Kritski $A L$, Graham SM,et al: Scale-up of services and research priorities for diagnosis, management,2010 Jun 19;375(9732):217991..

[7] Rafael E, Parker JE. Occupational and environmental medicine in the United States. International archives of occupational and environmental health. 1998 Apr 1;71(3):15561.

[8] Nicholson PJ. Occupational health in the European Union. Occupational medicine. 2002 Mar 1;52(2):80-4.

[9] Conway PM, Campanini P, Sartori S, Dotti R, Costa G. Main and interactive effects of shiftwork, age and work stress on health in an Italian sample of healthcare workers. Applied ergonomics. 2008 Sep 1;39(5):630-9.

[10] De Castro AB, Cabrera SL, Gee GC, Fujishiro $K$, Tagalog EA. Occupational health and safety issues among nurses in the Philippines. Aaohn Journal. 2009 Apr;57(4):149-57.

[11] Yassi A. Utilizing data systems to develop and monitor occupational health programs in a large Canadian hospital. Methods of information in medicine. 1998;37(02):125-9.

[12] Brott T, Adams Jr HP, Olinger CP, Marler JR, Barsan WG, Biller J, et al: Measurements of acute cerebral infarction: a clinical examination scale. Stroke. 1989 Jul;20(7):864-70. 
[13] Ndejjo R, Musinguzi G, Yu X, Buregyeya E, Musoke D, Wang JS, Halage AA, Whalen C, Bazeyo W, Williams P, Ssempebwa J. Occupational health hazards among healthcare workers in Kampala, Uganda. Journal of environmental and public health. 2015;2015.

[14] Nsubuga FM, Jaakkola MS. Needle stick injuries among nurses in sub-Saharan Africa. Tropical medicine \& international health. 2005 Aug;10(8):773-81.

[15] Ejilemele AA, Ojulu AC. Knowledge, attitude and practice of aspects of laboratory safety in Pathology Laboratories at the University of Port Harcourt Teaching Hospital, Nigeria. Nigerian Journal of clinical practice. 2005;8 (2):102-6.

[16] Colligan MJ, Cohen A. The role of training in promoting workplace safety and health. The psychology of workplace safety. 2004:22348.

[17] Siegel JD, Rhinehart E, Jackson M, Chiarello L. 2007 Guideline for isolation precautions preventing transmission of infectious agents in healthcare settings.

[18] Feinstein JS. The relationship between socioeconomic status and health: a review of the literature. Milbank quarterly. 1993 Jan 1;71 (2):279-322.

[19] Ziraba AK, Bwogi J, Namale A, Wainaina CW, Mayanja-Kizza H. Sero-prevalence and risk factors for hepatitis $B$ virus infection among health care workers in a tertiary hospital in Uganda. BMC infectious diseases. 2010 Dec;10(1):191.

[20] O'Toole M. The relationship between employees' perceptions of safety and organizational culture. Journal of safety research. 2002 Jun 1;33(2):231-43.

[21] Cooren F, Kuhn T, Cornelissen JP, Clark T. Communication, organizing and organization: An overview and introduction to the special issue. Organization studies. 2011 Sep;32 (9):1149-70.

[22] Wasswa P, Nalwadda CK, Buregyeya E, Gitta $\mathrm{SN}$, Anguzu P, Nuwaha F. Implementation of infection control in health facilities in Arua district, Uganda: a cross-sectional study. BMC infectious Diseases. 2015 Dec;15(1):268

[23] Colligan MJ, Cohen A. The role of training in promoting workplace safety and health. The psychology of workplace safety. 2004:22348. 